\title{
Skepticism, Criticism, and the Making of the Catholic Enlightenment: Rethinking the Career of Jean Hardouin
}

\author{
Daniel J. Watkins
}

Baylor University

Daniel_Watkins@baylor.edu

\begin{abstract}
This article evaluates the early career of the French Jesuit Jean Hardouin (1646-1729) and the impact that it had on other Jesuit scholars of the first decades of the eighteenth century. It argues that Hardouin's historical criticism - a response to skeptical critiques of the certainty of knowledge - pushed other Jesuit writers to consider new epistemological arguments and use new philosophical tools. In this way, Hardouin's career helped motivate French Jesuit engagement with the ideas and sensibilities of the Enlightenment.
\end{abstract}

\section{Keywords}

Jean Hardouin - skepticism - history - criticism - Enlightenment - Catholic Enlightenment

Of the many provocative statements uttered by French philosophes, few compare in audacity to the proclamation made by the Jesuit Jean Hardouin (16461729 ) at the beginning of his posthumously published Ad censuram scriptorum veterum prolegomena (1766) (Prolegomena on the censorship of the writers of antiquity). "It is my intention," Hardouin wrote, "to show that all writings which are commonly thought to be old, are in fact [...] suppositions, and the fabrication of an unprincipled crew of literary men."1 In brief, Hardouin

1 Jean Hardouin, The Prolegomena of Jean Hardouin, trans. Edwin Johnson (Sydney: Angus and Robertson, 1909), 1. The original work, written in Latin, was first published thirty-seven

(C) DANIEL J. WATKINS, 2019 | DOI:10.1163/22141332-00603005

This is an open access article distributed under the terms of the prevailing CC-BY-NC license at the time of publication. 
believed that the works of antiquity-including both the writings of many Greek and Roman authors as well as the texts of the church fathers-had been fabricated by a secret cabal of "atheists" in the fourteenth century. For three centuries, the cabal had gone undetected, but thanks to his tireless efforts, Hardouin felt that he had exposed their plot and rebuffed their arguments. Unleashing an attack on this impious cabal and their forgeries, Hardouin claimed that he was defending the Roman Catholic Church and indeed "religion itself."

Few in Hardouin's day believed him, but many knew of his theory. Voltaire (1694-1778) called him a "madman (fou)" and described his claim of widespread atheism as "ridiculous." ${ }^{3} \mathrm{He}$ became the butt of jokes around the Republic of Letters. ${ }^{4}$ Nicolas Malebranche $(1638-1715)$ sarcastically remarked in a letter to François de la Mothe Fénelon (1651-1715) that Hardouin's atheist conspiracy extended so far that he had to consider himself one of "the only worshippers of the true God," and the Jansenist weekly, the Nouvelles ecclésiastiques described him as "famous in the Republic of Letters by his perpetual delirium and paradoxes." ${ }^{5}$ For many in eighteenth-century France, Hardouin was an outsider, antithetical to the emerging "enlightened" age.

Historians have often followed the lead of these eighteenth-century commentators. Most intellectual histories of early modern France pay scant attention to Hardouin, and when they do mention him it is generally to summarize his conspiracy theory as a comical manifestation of the irrational amidst the more serious works of the Age of Reason. Owen Chadwick called him "typical of no one" and adopted Voltaire's language in labeling his scholarship

years after his death:Jean Hardouin, Ad censuram scriptorum veterum prolegomena (London: P. Vaillant, 1766).

2 Hardouin, Prolegomena, 2.

3 Voltaire to Pierre Joseph Thoulier d'Olivet, April 25, 1734, in The Complete Works of Voltaire, vol. 86, ed. Theodore Besterman et al. (Geneva: Institut et Musée Voltaire, 1968), letter D726, 466-67; Voltaire to Willem Jacob Gravesande, August 1, 1741, in The Complete Works of Voltaire, vol. 92, ed. Theodore Besterman et al. (Geneva: Institut et Musée Voltaire, 1968), letter D2519, $77-82$.

4 See, for example, Jean Ruivert's sardonic reference to Hardouin in his letter to Jean-Jacques Rousseau: Jean Ruivert to Jean-Jacques Rousseau (February 28, 1764), in Electronic Enlightenment Scholarly Edition of Correspondence, ed. Robert McNamee et al., Vers. 3.o (Oxford: University of Oxford, 2017), doi: http://dx.doi.org/10.13051/ee:doc/rousjeVFo190184bic (accessed January 25, 2019).

5 Nicolas Malebranche to François de la Mothe de Fénelon, June 1713, in CEuvres complètes, 23 vols., Correspondence, actes et documents, 1690-1715, ed. André Robinet (Paris: J. Vrin, 1961), 19:842; Mémoire pour servir à l'histoire de la Constitution Unigenitus [commonly and hereafter referred to as the Nouvelles ecclésiastiques], June 10, 1738:91. 
"madness." ${ }^{6}$ Arnaldo Momigliano (1908-87) too felt that his work went "well beyond the verge of madness." Even historians who have analyzed his writings in considerable depth have concluded that the Jesuit was a "singular" figureone who broke the mold of both the enlightened intellectual and the faithful Catholic. ${ }^{8}$ An anomalous figure at best and "madman" at worst, Hardouin has defied categorization and been separated from the intellectual currents of his day.

Hardouin was certainly unusual, but this does not mean that he was unimportant, nor does it mean that he was isolated from the intellectual trends of the late seventeenth and early eighteenth centuries. An exploration of his early scholarship and the reactions it prompted reveals that Hardouin both reflected and perpetuated significant intellectual transformations. Hardouin participated in a relatively common intellectual enterprise at the turn of the century, namely the pursuit of philosophical and historical certitude amidst what Paul Hazard (1878-1944) has labeled la crise de la conscience européenne. ${ }^{9}$ Hardouin took seriously the challenge of Pyrrhonian skepticism and dedicated himself to both appropriating and responding to it in defense of the church. Although his scholarship ended in a particularly notable and outlandish conclusion, in attempting to establish new foundations for Catholic authority, he displayed a commitment to critical inquiry and drove many of his colleagues to explore new philosophical and theological arguments. This reassessment of Hardouin's career clarifies why other French Jesuits adopted new epistemologies and critical methods at the turn of the eighteenth century. Hardouin's publications served as catalysts for French Jesuit participation in the Catholic Enlightenment, an effort by Catholic intellectuals, in the words of Ulrich Lehner, "to use the newest achievements of philosophy and science to defend the essential dogmas of Catholic Christianity by explaining them in a new language, and $[\ldots]$ to reconcile Catholicism with modern culture."10 Both Hardouin's detractors and supporters within the French Society of Jesus built their work—and

6 Owen Chadwick, From Bossuet to Newman: The Idea of Doctrinal Development (Cambridge: Cambridge University Press, 1957), 51.

7 Arnaldo Momigliano, "Ancient History and the Antiquarian," Journal of the Warburg and Courtauld Institutes 13, no. 3-4 (1950): 285-315, here 303.

8 Bruno Neveu, Érudition et religion aux XviIe et XVIIIe siècles (Paris: Albin Michel, 1994), 57.

9 Paul Hazard, The Crisis of the European Mind, 1680-1715, trans. James Lewis May (New York: New York Review of Books, 2013) (originally published in French in 1961).

10 Ulrich Lehner, The Catholic Enlightenment: The Forgotten History of a Global Movement (New York: Oxford University Press, 2016), 7. On the concept of a Catholic Enlightenment, see also Ulrich Lehner and Michael Printy, eds., A Companion to the Catholic Enlightenment in Europe (Leiden: Brill, 2010); Bernard Plongeron, "Recherches sur l'Aufklärung 
the contributions they made to the Catholic Enlightenment—on the foundation of his scholarship. The curious career of Hardouin allows historians to see how the Catholic Enlightenment was not only a response to the provocative ideas of philosophes outside the church but also a response to controversialists within the church.

\section{$1 \quad$ Skepticism and Criticism: Hardouin's System}

Hardouin's scholarly career emerged amidst a revival of philosophical skepticism in France. Born the son of a printer and bookseller in Brittany, Hardouin entered the Jesuit novitiate in 1660 and became a fully professed member of the Society of Jesus in $1681 .{ }^{11}$ He was quickly recognized by his superiors as a talented scholar and, as a result, spent the five years after his profession as a scriptor librorum, or a full-time writer for the Society. ${ }^{12}$ Hardouin began writing at a moment when skepticism was reaching new heights within the scholarly community of Paris. Pyrrhonian skepticism - a philosophical tradition dating back to Pyrrho of Elis (c.36o-275 BCE) that maintained that true and complete knowledge was impossible for the human mind-had reappeared on the European intellectual scene thanks largely to the work of Michel de Montaigne

catholique en Europe occidental, 1770-1830," Revue d'histoire moderne et contemporaine 16 (1969): 555-605.

11 Carlos Sommervogel, Bibliothèque de la Compagnie de Jésus, nouvelle édition, 12 vols. (Brussels: Oscar Schepens, 189o), 4:84; Diccionario histórico de la Compañía de Jesús: Biográfico-temático, 4 vols. (Rome/Madrid: IHsi/Universidad Pontificia Comillas, 2001), 2:1880.

12 Shortly thereafter Hardouin became a professor of Scripture at the Collège Louis-leGrand in Paris until 1691 when he was removed from this position and made the collège's librarian. According to Gustave Dupont Ferrier (1860-1956), he was one of the only professors of Scripture to both teach and publish while in his post, and as a librarian Hardouin's scholarly production only increased. The result was a staggeringly prolific career. In the words of Robert Palmer, he was a "prodigious worker [...] whose labors are all but incredible today." See Sommervogel, 4:84; $D H C J$, 2:1880; Gustave Dupont-Ferrier, Du Collège de Clermont au Lycée Louis-le-Grand (1563-1920): La Vie quotidienne d'un collège parisien pendant plus de trois cent cinquante ans, 3 vols. (Paris: E. Boccard, 1925), 3:34; Catherine Northeast, The Parisian Jesuits and the Enlightenment, 1700-1762, Studies in Voltaire and the Eighteenth Century 288 (Oxford: Voltaire Foundation, 1991), 82; Adrien Paschoud, "L'érudition au péril de la foi: L'œuvre apologétique de Jean Hardouin," in Apologetique, 1650-1802: La Nature et la grâce, ed. Nicolas Brucker (Berne: Peter Lang, 2010), 201-15, here 202; Robert R. Palmer, Catholics and Unbelievers in Eighteenth-Century France (Princeton, NJ: Princeton University Press, 1939), 65-66. 
$(1533-92)$ and the publication of a new edition of Sextus Empiricus's (c.16o-210 CE) Adversus mathematicos (Against mathematicians, 1569) in the sixteenth century. ${ }^{13}$ Deployed by French Catholics as a way of combating the arguments of Protestants during the tumultuous years of the Reformation, Pyrrhonism proved useful in the seventeenth century for those who wished to criticize competing philosophical systems. Pierre Gassendi (1592-1655), for example, used skeptical arguments to question the reliability of sense perception and thus the conclusions of the Scholastics. ${ }^{14}$ François de La Mothe Le Vayer (15881672) promoted a "Christian Pyrrhonism" that pushed Catholics away from a reliance upon rational inquiry for the content of belief and toward a "blind fideism" that was non-dogmatic and thus freed from the religious quarrels that had dominated the previous century. ${ }^{15}$ By the 1680 s, a new generation of skeptics, among them Pierre-Daniel Huet (1630-1721) and Pierre Bayle (1647-1706), inherited the arguments of previous years and continued to apply them in new ways - in Huet's case against the rationalist theories of René Descartes (1596-1650) ${ }^{16}$ Members of the Society of Jesus had shown an interest in skeptical debates too because of their implications for apologetics. So comfortable were many French Jesuits with skepticism that Huet himself eventually retired to the main Jesuit house in Paris, the Maison professe. ${ }^{17}$ As a scriptor librorum at a moment of skeptical revival, thus, Hardouin was well aware of the value of Pyrrhonian arguments and appropriated them as a foundation for much of his early work.

Skepticism offered some theological advantages, but it also posed problems. The concession that certain knowledge was impossible threatened to undermine the stability of many of the most important theological tenets of the Catholic faith, including belief in the existence of God. Freshly professed, Hardouin understood the double-edged sword that was skepticism and endeavored to wield it safely. Like many historians at the time, Hardouin sought to address the challenges of skepticism by grounding historical knowledge on sources outside of the traditional canon of classical texts. Consequently, he began his scholarly career by focusing on the field of numismatics, or the study

13 For a more thorough definition of Pyrrhonian skepticism, its origins, and the differences between it and other forms of ancient skepticism, see Richard Popkin, The History of Scepticism: From Savonarola to Bayle, revised and expanded edition (Oxford: Oxford University Press, 2003), xvii-xxiii.

14 Popkin, History of Scepticism, 78, 91-92; Anton M. Matytsin, The Specter of Skepticism in the Age of Enlightenment (Baltimore: Johns Hopkins University Press, 2016), 33.

15 Popkin, History of Scepticism, 82-83; Matytsin, Specter of Skepticism, 29-30.

16 Popkin, History of Scepticism, 278-79; Matytsin, Specter of Skepticism, 96-97.

17 Northeast, Parisian Jesuits, 55 . 
of ancient coins..$^{18}$ In 1681, one of the premier scholarly periodicals in France, the Journal des sçavans publicized the first fruits of his efforts. The article described how Hardouin used coins to clarify a question of historical accuracy in Pliny the Elder's (23-79 CE) Naturalis historia (Natural history, c.77-79 $\mathrm{CE}$ ), illustrating Hardouin's belief that since coins were harder to manipulate than texts the evidence that they provided was fundamentally more reliable. Numismatics became the chief way that Hardouin proposed to establish historical certainty while simultaneously employing the arguments of historical skepticism against the Jesuits' opponents. ${ }^{19}$

Coins, however, could not always provide the full story, and Hardouin was forced to create a critical apparatus to help him establish certitude with texts. Hardouin's system was predicated on a few firm convictions. First, as specified above, if the information in a text was corroborated by original materials, such as coins, then it could be considered valid. It therefore followed that texts that were affirmed as valid by other texts whose legitimacy had already been established (generally by reference to numismatic materials) could also be trusted. The lack of numismatic or other types of corroborating evidence for a textual source, however, immediately cast doubt on the reliability of the source in question. Second, textual sources, like coins, must be read literally. Hardouin maintained that the reader should always approach a historical document as it was written and not with a metaphorical or allegorical lens. Allegory, for Hardouin, was a sign of manipulation — an indication that a reader had modified the meaning of a text to fit a predetermined, teleological end. ${ }^{20}$ Finally, any

18 For more on numismatics in the seventeenth century and the impact it had on transforming historical scholarship in Europe, see Neveu, Erudition et religion, 26-27, 50-59; Momigliano, "Ancient History and the Antiquarian," 303.

19 Journal des sçavans [hereafter JS], March 10, 1681: 73-84. Hardouin followed up this initial work with a host of publications on numismatics, including, most notably, his Nummi antique populorum et urbium illustrati (1684) and his Chronologiae ex nummis antiquis restitutae prolusio de nummis Herodiadum (1693). These and many of his other early works on numismatics can be found in a collection of his writings titled Opera selecta [hereafter OS] (Amsterdam: De Lorme, 1709). For a list of articles on the subject of coins that he published in both the Journal des sçavans and the Journal de Trévoux, see Sommervogel 4:84-105. For a more thorough treatment of Hardouin's numismatics scholarship, see Anthony Grafton, Bring Out Your Dead: The Past as Revelation (Cambridge, MA: Harvard University Press, 2001), 181-207.

20 This was most provocatively exhibited in Hardouin's promotion of solely "literal" readings of the prophecies of the Old Testament, the results of which were often controversial denials that previously accepted "messianic" prophecies referred to the person of Jesus. For further explanation, see Northeast, Parisian Jesuits, 127-29. 
text that included internal inconsistencies or historical anachronisms must be considered illegitimate. Hardouin was particularly sensitive to anachronisms in language, and as a talented linguist, he based much of his criticism on the Latinity of authors and on whether they fit the style and lexicon of the time from which they were alleged to originate. Armed with this "system," Hardouin set out to write history that, in his mind, could be assured in its validity.

No work better displayed Hardouin's critical approach than his Chronologia Veteris Testamenti (Chronology of the Old Testament, 1697). ${ }^{21}$ The Chronologia Veteris Testamenti applied Hardouin's numismatic research and literal reading of texts to the task of deducing the correct sequence of events of the Old Testament. For the earlier sections of his chronology, Hardouin relied largely upon inter-textual evidence from the Bible. ${ }^{22} \mathrm{He}$ maintained his strictly literal reading of the Vulgate, for example, when proposing that the creation of the world took place over the course of seven days, and when deducing the year of the great flood of Noah by adding together the ages of the early patriarchs from Adam to Noah. ${ }^{23}$ When the timeline advanced, Hardouin was able to incorporate more information from coins. He depicted the era following the conquest of Alexander the Great (356-23 BCE), for example, primarily using numismatic evidence supplemented only sporadically by passages from the books of the Maccabees and Pliny's Naturalis historia. ${ }^{24}$ Indeed, Hardouin's analysis of both Roman and Greek coins made it possible to fill the major gap in the historical narrative of the Bible, namely the era between the Maccabean period to the birth of Jesus. ${ }^{25}$

In applying his critical method, however, Hardouin found that many of the texts upon which prior historians had depended in their constructions of the past did not pass his litmus test of legitimacy. According to it, if a text could neither be supported by evidence from original materials, nor remain internally consistent based on literal readings, then it could not be plausibly

21 Jean Hardouin, Chronologia Veteris Testamenti, ad Vulgatam versionem exacta et nummis antiquis subinde illustrata (Paris: Boudot, 1697). Hardouin's Chronologia Veteris Testamenti was included in his Opera selecta, and it is this version that I will cite hereafter.

Hardouin took the Vulgate to be an authentic source largely based on the Council of Trent's (1545-63) ruling that it was authoritative and on, what he felt was, its internal consistency. For explanations of why he deemed the Vulgate trustworthy, and subsequently, why he felt that it was more trustworthy than the Greek manuscripts of the Bible including the Septuagint, see OS, 513-14; Hardouin, Ad censuram scriptorum, 61, 68-69, 73.

$24 O S$, 575-92.

25 OS, 610-19. 
defended as an authentic account of the past regardless of its esteem by previous historians or the church. The more Hardouin scoured the sources of antiquity, the fewer reliable texts he found. Textual problems and a lack of support from coins led Hardouin to question whether the works of antiquity were in fact products of the times to which they had been conventionally attributed. Thus by 1693, Hardouin had determined that nearly all the works of Latin and Greek antiquity - excepting the writings of Cicero (106-43 вСЕ), Pliny, Virgil's (70-19 вСЕ) Georgics (c.29 CE), and Horace's (65-8 вСE) Satires (c.35-33 вСЕ) and Epistles (c.20-14 BCE) - were not only unfit based on Hardouin's analysis of existing coins - and were, thus, unreliable sources for the past—but, to his judgment, also contained textual deficiencies that compromised their authenticity as actual documents from antiquity. ${ }^{26}$ Very few historical texts held up to his standards of criticism, and, thus, the histories that they espoused could not be considered definitively reliable.

Hardouin's grand theory about the fabricated nature of much of ancient history arose from his efforts to respond to skeptical arguments of the late seventeenth century and equip scholars with a new critical method upon which they could establish historical truth. So committed was Hardouin to his critical method that he was willing to declare as inauthentic not only writings from secular authors but also many of the texts of the church fathers and even some of the manuscripts of the ecumenical councils. In trying to explain the existence of so many unreliable documents, Hardouin eventually devised his conspiracy about a cabal of forgers. It is important to note, however, that the efforts which preceded this conspiratorial end were born out of serious concerns over skeptical challenges to the legitimacy of historical texts and an honest attempt to answer them. ${ }^{27}$ Although Hardouin's suppositions resulted in an exceptional conclusion, they emerged out of a what was a common intellectual enterprise for many late seventeenth-century scholars. Fellow Jesuit Claude Buffier (1661-1737) and other Catholic apologists, including Abbé d'Houtteville (1686-1742) and Abbé de Prades (1721-82), shared in Hardouin's exploration of the field of history as a way to establish certainty amidst growing doubt well into the eighteenth century. ${ }^{28}$ For Hardouin as well as many notable scholars of the early Enlightenment, skepticism provided the intellectual impulse for testing new philosophical systems.

\footnotetext{
26 Hardouin, Chronologiae ex nummis Herodiadum, 6o-61.

27 Grafton also makes this case in his assessment of Hardouin and his relationship with the Republic of Letters; see Grafton, Bring Out Your Dead, 181-207.

28 Burson, Rise and Fall of Theological Enlightenment, 208-13.
} 
Paradoxically, many in the late seventeenth and early eighteenth centuries viewed Hardouin's criticism not as a solution to the problem of skepticism, but rather as another manifestation of it. Hardouin had clearly conceded much to the skeptical position on history. Recognizing the danger of having even one of their writers question the validity of texts that were widely accepted as authentic and authoritative, the superiors of the Jesuit province of France "demoted" him from professor of Scripture to librarian at the Collège Louis-le-Grand in $1691 .{ }^{29}$ Fifteen years later, Michel Le Tellier (1643-1719), the soon-to-be superior of the province of France, took the matter further and launched formal inquiries into Hardouin and his system at the behest of the superior general, Michelangelo Tamburini (1648-1730). ${ }^{30}$ Hardouin's work threatened the intellectual reputation of the Jesuits, and so his superiors sought to sideline him and contain it.

The depositions before Le Tellier in addition to the letters sent back to Tamburini detailed the concerns Hardouin's colleagues had with his system. In brief, they agreed that his books contained ideas that were problematic, untenable, or simply dangerous for the Catholic Church and the Society of Jesus. ${ }^{31}$ For Louis Marquer (1653-1725), it was the "ignorant and calumnious accusation" that the writings of the church fathers were false that posed the biggest problem. ${ }^{32}$ Henri-Charles Forcet $\left(165^{0}-1729\right)$ claimed that Hardouin's critical system unacceptably compromised the integrity of "church as well as profane history" 33 Aghast at his cavalier colleague's willingness to wantonly discard the opinions of previous theologians, Louis Doucin (1652-1726) reprimanded Hardouin for acting as "someone who could separate himself [from past interpretations] by the characteristic of his singular intellect." 34 The near

29 Paschoud, "L'érudition au péril de la foi," 202. The notion that Hardouin was stripped of his teaching duties because of his controversial take on Augustine was promoted by fellow Jesuit Pierre Amys. See "Memoire par P. Amys touchant le livre du P. Berruyer," November 7, 1728, Stonyhurst College, Papers of Mathurin Le Forestier, A II 27, vol. 1, no. 17. The documents from Le Forestier A II 27, vol. 1 will hereafter be cited Stonyhurst.

$30 \quad$ Northeast, Parisian Jesuits, 82.

31 The most detailed assessment of what some Jesuits felt were problematic comes in the form of an anonymous memoir sent to Joseph de Gallifet, the assistant of France in Rome, listing over forty "paradoxes" included in the Chronologia Veteris Testamenti: "Doctrina Joannis Harduini ab uno e suis accusatoribus expositas," Stonyhurst, no. 1.

32 Louis Marquer to Michelangelo Tamburini, September 1, 1707, Stonyhurst, no. 8.

33 Henri-Charles Forcet to Michelangelo Tamburini, August 29, 1707, Stonyhurst, no. 6.

34 Louis Doucin to Michelangelo Tamburini, August 14, 1707, Stonyhurst, no. 9 b. 
dozen Jesuits who wrote to Tamburini in the summer of 1707 all affirmed that Hardouin's system posed enough of a danger to the institution of the church to warrant its suppression.

Hardouin's superiors were soon forced to publicize their disapproval of his system after he published his Opera selecta (Selected works), an anthology of writings that included many of his most controversial pieces to date, in $1709 .{ }^{35}$ Printed in the Journal de Trévoux shortly after the appearance of the Opera selecta, the "Declaration" of the four superiors of the province of France clearly and concisely distanced the Society from Hardouin's views. They admitted, for example, that the Opera selecta contained works "that we wish had never seen the light of day." ${ }^{36}$ They detailed their previous efforts to suppress these works, moreover, including their attempts to seize all copies of Hardouin's most controversial books that they could find, and claimed that many of the other works included in the Opera selecta that had not been published previously never passed before their censors' eyes. ${ }^{37}$ They also clarified their positions on some of his theses, listing five that they found particularly problematic. ${ }^{38}$ Finally, following their "Declaration," they included a brief retraction by Hardouin himself professing that he too "condemn[ed] what [the Declaration] condemns."39 The publication of the Opera selecta forced the Jesuit superiors of France to take what had previously been an internal disciplinary matter and transfer it to the realm of public debate.

Not content to simply denounce Hardouin's system, some Jesuits felt obliged to refute it by promoting intellectual alternatives. The figure most involved in this effort was undoubtedly René-Joseph Tournemine (1661-1739). ${ }^{40}$ Tournemine was one of Hardouin's chief rivals and had worked for decades to limit the spread of Hardouin's ideas. Even before the Opera selecta, he published a refutation of Hardouin's critical system titled Douze impossibilités du système $d u$ P. Hardouin (Twelve impossibilities of the system of Father Hardouin) that

35 The Opera selecta included both the Chronologiae ex nummis Herodiadum and the Chronologia Veteris Testamenti and was published covertly against the will of Hardouin's superiors. For the fascinating story of how Hardouin covertly published the Opera selecta against the wishes of his superiors, see Northeast, Parisian Jesuits, 127.

36 Mémoires pour l'histoire des sciences et des beaux-arts [commonly referred to as the Journal de Trévoux and hereafter cited, JT], February 1709, 367.

37 JT, February 1709, 367-68.

$38 \quad J T$, February 1709, 368-69.

$39 J T$, February 1709, 371. Many of his colleagues doubted the authenticity of Hardouin's retraction; see "Doutes sur la sincérité de la protestation," Stonyhurst, no. 12.

40 For more on Tournemine, see in this issue Michela Catto, "Chinese Atheism in the Mémoires de Trévoux: A Cultural Project against the Existence of a Perfect Atheism." 
is, unfortunately, now lost. ${ }^{41}$ Meanwhile, he was also working on an entirely different historical chronology of the Old and New Testaments that would rival Hardouin's Chronologia Veteris Testamenti. Instead of relying solely on the Vulgate and numismatic materials, as Hardouin had, Tournemine's chronology privileged the critical and comparative analysis of sacred and profane texts. Rejecting Hardouin's delegitimization of these materials, Tournemine argued that it was the corroboration of evidence presented in both sacred and profane sources that assured the accuracy of his history. In contrast to Hardouin, Tournemine felt that textual sources could be trusted, but recognizing the challenge of historical skepticism to such sources, he advanced the proposition that only the adoption of a multiplicity and diversity of sources could assure the reliability of a historical account. ${ }^{42}$

Similarly, Tournemine likely had Hardouin in mind when promoting the power of reason to establish historical truths. In his review of a posthumously published collection of Hardouin's later works, titled the Opera varia (Various works), Tournemine repeated the Society's official disavowal of Hardouin's "strange system" but also ventured to combat Hardouin's theories by calling for a rational, epistemological modesty. ${ }^{43}$ First, he attacked Hardouin's claim that the great conspiracy of forged texts had gone unnoticed for centuries by arguing that this assertion implausibly assumed the "profound ignorance of the rest of the world" while implying Hardouin's distasteful overconfidence in his own abilities. Second, Tournemine charged Hardouin with supplying inadequate evidence to support his claims. To argue that lack of evidence was, in fact, the very evidence necessary to demonstrate the success of Hardouin's impious cabal of forgers was merely to engage in "circular reasoning" according to Tournemine. ${ }^{44}$ This critique of Hardouin mirrored Tournemine's more explicit promotion of reason as a key weapon against skepticism in his essay, "De la liberté de penser sur la Religion" (On the freedom of thought about religion), published in the Journal de Trévoux two years later (1736). In this essay, Tournemine attacked supposed "unbelievers"-denouncing by name the likes of the Anthony Ashley-Cooper, Third Earl of Shaftesbury (1671-1713), John

41 Jacques George de Chauffepié, Nouveau dictionnaire historique et critique pour servir de supplement ou de continuation au Dictionnaire historique et critique de Mr. Pierre Bayle, 4 vols. (Amsterdam: Z. Chatelain et Fils, 1756), 4:474; Sommervogel, 8:180. Catherine Northeast and Adrien Paschoud both confirm that the work is lost. See Northeast, Parisian Jesuits, 87; Paschoud, "L'érudition au péril de la foi," 213.

$42 J T$, May 1706, 808-22.

$43 J T$, January $1734,76-77$.

$44 J T$, January $1734,82$. 
Toland (1670-1722), and Bayle among others-by claiming that most had not, in fact, considered the preponderance of historical evidence attesting to the likely reality of Christian revelation. ${ }^{45}$ Tournemine's confrontation with Hardouin pushed him to develop the rational arguments that he would continue to employ against more notable skeptics.

Tournemine's responses to Hardouin contributed to a trend increasingly evident among eighteenth-century Jesuit writers who took seriously the explanatory power of empiricism to combat skeptical challenges. Claude Buffier, in his Traité des premieres véritez (Treatise on first truths, 1724), made considerable contact with John Locke (1632-1704) in arguing that knowledge comes from both the sentiment intime of each individual as well as the corporate sentiment commun de la nature that connects with observation of the external world ${ }^{46}$ In a less metaphysical and more historical mode, Dominique de Colonia (1660-1741) also shared Tournemine's concern for the importance of consulting and juxtaposing a diversity of evidence in support of historical claims. In his La Religion chrétienne autorisée par le temoignage des anciens auteurs payens (The Christian religion authenticated by the testimony of ancient pagan authors, 1718), he approached the task of Christian apologetics by way of an analysis of non-Christian sources, pulling out those passages where Roman authors either mentioned Jesus, confirmed elements of his divinity, or provided other corroborating evidence for the claims of the church ${ }^{47}$ So too did the work of Jesuits Etienne Souciet (1671-1744) and Jean-Baptiste Du Halde (1674-1743) bring evidence from Chinese sources to bear on questions of historical chronology — the latter using them, in fact, to refute chronologies built upon the Vulgate (among which Hardouin's was one example) ${ }^{48}$ While not all of these works specifically addressed Hardouin as Tournemine did, they shared in the increasingly common Jesuit trend of finding new bases for historical certainty in the wake of Hardouin's critical challenge. That Hardouin's

$45 J T$, January 1736, 98-116. It should be noted, however, that Tournemine was not always opposed to skeptical arguments. See Matytsin, Specter of Skepticism, 74-75.

46 Claude Buffier, Traité des premieres véritez et de la source de nos jugemens (Paris: Didot, 1724); Jeffrey D. Burson, "Claude G. Buffier and the Maturation of the Jesuit Synthesis in the Age of Enlightenment," Intellectual History Review 21, no. 4 (2011): 460-62.

47 Dominique de Colonia, La Religion chrétienne autorisée par le temoignage des anciens auteurs payens, 2 vols. (Lyon: Plaignard, 1718); Northeast, Parisian Jesuits, 135-36.

48 Etienne Souciet, ed., Observations mathématiques, astronomiques, geographiques, chronologiques, et physiques: Tirées des anciens livres chinois ou faites nouvellement aux Indes et à la Chine, 3 vols. (Paris: Rollin, 1729-32), esp. vols. 2-3; Jean-Baptiste Du Halde, Description geographique, historique, chronologique, politique, et physique de l'Empire de la Chine et de la Tartarie Chinoise (Paris: Le Mercier, 1735), 1:265-67; Northeast, Parisian Jesuits, 121. 
historical criticism somehow influenced Jesuit scholars' advancement of empirical, evidence-based historical methods, moreover, should not come as a surprise considering that other érudits outside of the Society used a refutation of Hardouin's theory of the illegitimacy of ancient texts to advocate for their own methods of establishing historical certainty_-perhaps the best example being the Calvinist pastor David Renaud Boullier's (1699-1759) Traité des vrais principes qui servent de fondement à la certitude morale (Treatise on the true principles that serve as the foundation for moral certitude, 1737). ${ }^{49}$ As Hardouin's works became more widely known, so too did responses to them and the promotion of competing philosophical and historical methods that drew from some of the most significant intellectual trends of the early Enlightenment.

Despite his objections to Hardouin's critical system, Tournemine admitted in his refutation of the Opera varia that Hardouin was nevertheless "prodigiously well read" and had amassed "profound knowledge" and "inimitable insight." Others within the Society agreed. Few adopted the conclusions of his lavish conspiracy, but many Jesuits valued aspects of Hardouin's work and expanded upon them. In this way, Hardouin's system - or, rather, parts of it-lived on and became foundational for new Jesuit intellectual projects in the first half of the eighteenth century. Hardouin's so-called "disciples" ranged from young members of the Society to older, more established figures. Utilizing Hardouin's premises, they pushed the Society of Jesus further into the world of the Catholic Enlightenment by searching for new ways to present and defend the history and authority of the church.

Among those implicated as a "disciple" of Hardouin was Jean-Mathias Mahoudeau (1671-1735). Pierre Amys (1650-1735) and Etienne Souciet both agreed that Mahoudeau, a professor of Scripture at the Collège Louis-le-Grand in Paris, was deeply invested in Hardouin's system..$^{51}$ Indeed, Amys found Mahoudeau so "faithful to his master" that between Mahoudeau and Hardouin he could not "see the difference." 52 Hardouin launched Mahoudeau's scholarly career. Mahoudeau's work focused on astronomy, or, more specifically, astronomical

\footnotetext{
49 Matytsin, Specter of Skepticism, 253-54.

50 JT, January 1734, 111.

51 Stonyhurst, no. 17; Souciet to [Tamburini], October 17, 1729, Stonyhurst, no. 26; Northeast, Parisian Jesuits, 129.

$5^{2}$ Stonyhurst, no. 17.
} 
calculations applied to history. His magnum opus was Le Calendrier Mosaïque des ecrivains sacrez (The Mosaic calendar of the sacred writers), a mathematical work in which he attempted to connect the Hebrew, Julian, and Gregorian calendars and, in so doing, use them to produce a stable chronology for biblical history. The work never made it to print, but a prospectus relaying its author's intentions and methods achieved publication in the Journal de Trévoux. ${ }^{53}$

In his prospectus, Mahoudeau admitted the discrepancies in historians' opinions on the matter of biblical chronology and opined that this lack of agreement produced a "dangerous incertitude" in religious matters that led people to no longer be "disposed to respect the word of God." 54 To settle the matter once and for all while defending the church against "unbelief," Mahoudeau proposed a new study of biblical chronology based on a reading of the scriptures and a reconciliation of the dates described there with astronomical calculations of the earth's revolutions around the sun. Although Mahoudeau described this approach as novel, he acknowledged the contributions of one "single learned interpreter of both the sacred and profane authors" who had "for thirty years" been working to establish a method for understanding sacred history-a not-so-subtle homage to Hardouin whose Chronologia Veteris Testament $i$ had appeared some thirty-four years prior. ${ }^{55}$ Mahoudeau clearly followed Hardouin's lead, both in criticizing the "inattention (inadvertence)" of "the majority of interpreters of the holy scriptures" to the problem of varying astronomical calendars, and in basing his method on the analysis of the Vulgate and his calculations alone. ${ }^{56}$ By following this plan, Mahoudeau claimed he would be able to "understand and account for with complete certitude, the characteristics of the times so distinctly marked in the books of Moses, the other historical books [of the Bible], and in all other places of the holy scriptures." ${ }^{57}$ Although the work never came to fruition, pieces of it, particularly many of the calculations that he did in formulating equations to compare dates within the various calendars, appeared in subsequent articles in the Journal de Trévoux. ${ }^{58}$ The result was a dizzying display of mathematical computation

\footnotetext{
53 Sommervogel, 5:321.

$54 J T$, September $1727,1637-38$.

$55 J T$, September 1727,1639 . Mahoudeau ended his prospectus with an even more conspicuous nod to Hardouin when he pointed out that the design of his work had received an "approbation" from the "famous commentator of Pliny in his second edition," a reference to Hardouin's second edition of Pliny's Naturalis historia which had been published in 1723. See JT, September 1727, 1653; Northeast, Parisian Jesuits, 143.

$56 \quad J T$, September 1727,1638 .

57 JT, September 1727, 1650.

$5^{8}$ See for examples: JT (1728), 1435-61, 1639-66; (1733), 445-75, 830-67, 1151-86, 1400-27.
} 
and its application to a significant historical quandary for church history. Taking Hardouin's initial premise that one ought to read the biblical accounts of ancient Hebrew history literally while discarding the "unreliable" analyses of outside interpreters, Mahoudeau expanded upon Hardouin's historical criticism by attempting to provide it with a stronger mathematical foundation, all for the purpose of more firmly establishing the credibility of the sacred narrative.

Hardouin's scholarship was perhaps most impactful in advancing Jesuit biblical criticism in the eighteenth century. By tearing down the edifice of church authorities, Hardouin allowed biblical critics far more freedom to explore new interpretations of the biblical text and to translate the text itself in new ways. One of the first manifestations of this was Barthélemi Germon's (1663-1718) De veteribus haereticis ecclesiasticorum codicum corruptoribus (On the ancient heretical corruptors of the ecclesiastical codices, 1713). ${ }^{59}$ Although he vehemently denied having adopted Hardouin's conspiracy theory, Germon applied a similar type of criticism as Hardouin to his scholarship. ${ }^{60}$ His book was both a study of the ways that heretics throughout the church's history had used and abused the scriptures to fit their particular theological agendas and an explanation of how certain manuscript codices reflected those errors. The plan clearly grew from Hardouin's project of source criticism. Yet in so doing, Germon entertained a fairly novel theory of biblical criticism, namely that sacred texts could fall prey to corruption without necessarily destroying the veracity of the Catholic faith or the usefulness of the scriptures themselves. The "offenses of wicked men," argued Germon, "in no way has harmed" and indeed has left "unshaken the authority of tradition."61 Germon admitted that there were errors in biblical codices but claimed that the recognition of these errors "did not bring about religious Pyrrhonism"; instead, he theorized, the scriptural texts could retain their theological and moral value outside of these discrepancies because the traditions of the church confirmed what in the scriptures were

59 Barthélemi Germon, De veteribus haereticis ecclesiasticorum codicum corruptoribus (Paris: Le Comte \& Montalant, 1713). On Germon's connections to Hardouin, see the testimonies of some of his colleagues: Forcet to Tamburini, August 29, 1707, Stonyhurst, no. 6; "Deposition du P. Desconseils item ce qui regarde La Piloniere," Stonyhurst, no. 5; "Doutes sur la sincérité de la protestation," Stonyhurst, no. 12.

60 Barthélemi Germon to Michelangelo Tamburini, July 4, 1707, Stonyhurst, no. 20. Amys, normally the most ardent whistle blower in the Society, attested to Germon's sincerity and to the fact that he promised "never [to] give in to [Hardouin's] visions." See Stonyhurst, no. 17 .

61 Germon, De veteribus haereticis, 557. 
important and reliable. ${ }^{62}$ Like Mahoudeau, Germon's exploration of new theological arguments grew out of the adoption of certain principles promoted by Hardouin and his system.

Yet undoubtedly Hardouin's most notable "disciple" and the one who carried his work furthest in the realm of biblical studies was Isaac-Joseph Berruyer (1681-1758). The connection between Hardouin and Berruyer was most evident in the latter's chief literary production: the Histoire du peuple de Dieu (History of the people of God, 1728). The Histoire was a colorful paraphrase of the Bible in eighteenth-century vernacular French, and Berruyer published it in three sections over the course of thirty years. ${ }^{63}$ Hardouin's critical scholarship was the foundation upon which the Histoire was built. First, Berruyer chose to base his paraphrase solely on the text of the Vulgate, explaining in a manner reminiscent of Hardouin that it was "the original text of the holy scriptures" and the only truly authentic version. ${ }^{64}$ Second, he adopted Hardouin's biblical chronology in its entirety, organizing the sequence of events in his narrative around Hardouin's judgments rather than the order of the biblical books themselves. Indeed, Berruyer was so adamant a supporter of Hardouin's historical chronologies that he included the exact dating that Hardouin gave to biblical events in the margins of each page of the Histoire and, in a revised edition of the first section of the book, included tables that displayed the precise calculations of Hardouin's dating of the entire period discussed in the Old Testament. ${ }^{65}$ In addition, the third section of his Histoire, paraphrasing the Epistles, was

62 Germon, De veteribus haereticis, 558. For more analysis of Germon's book, see Bernard Chedozeau, "Le P. Hardouin et le refus du rationalisme en religion," Revue des sciences philosophiques et théologiques 79 (1995): 249-81, here 267-70.

63 Isaac-Joseph Berruyer, Histoire du Peuple de Dieu depuis son origine jusqu'à la Venue du Messie tirée des seuls livres Saints ou le texte sacré des Livres de l'Ancien Testament réduit en un corps d'histoire, 8 vols. (Paris: Knapen, 1728); Histoire du Peuple de Dieu depuis la Naissance du Messie jusqu'à la fin de la Synagogue, tirée des seuls Livres Saints ou le Texte sacré du Nouveau Testament réduit en un corps d'histoire, 8 vols. (La Haye: Neaulme, 1753); Histoire du Peuple de Dieu, troisième partie ou Paraphrase des Epîtres des Apôtres d'après le commentaire latin du P. Hardouin, 2 vols. (La Haye: Neaulme, 1757). For more on the publication history of the Histoire see my doctoral dissertation: Daniel J. Watkins, "Enlightenment, Catholicism, Conservatism: The Isaac-Joseph Berruyer Affair and the Culture of Orthodoxy in France, ca. 1700-1830" (PhD diss., The Ohio State University, 2014).

64 Berruyer, Histoire du peuple de Dieu, première partie, 1:xlv-xlviii.

65 Isaac-Joseph Berruyer, Supplément à la première édition de l'histoire du Peuple de Dieu, tiré de la nouvelle édition de 1734 contenant la suite des Prophéties de l'ancien Testament, l'Histoire de Job, les cartes nécessaires pour l'intelligence de l'Histoire Sainte, des Sommaires chronologiques, et une table générale des matières qui sont renfermées dans tout l'ouvrage (Paris: Prault, 1734). 
simply a "literal paraphrase" of Hardouin's Commentarius in Novum Testamentum (Commentary on the New Testament, 1741) that essentially translated Hardouin's paraphrase of the Vulgate rather than the Vulgate itself. ${ }^{66}$ In the preface to the work, Berruyer provided his own defense of Hardouin, lauding his "insight and his ability" despite the "lapses that some have reproached him for." To Berruyer, Hardouin was "a great man," and he confessed that there was not "a more enlightened guide than him." 67

Having initially established his book on the foundation of Hardouin's scholarship, Berruyer proceeded to transform the Histoire into an Enlightenment Bible. ${ }^{68}$ Berruyer dramatically humanized the person of Jesus to a degree that was, arguably, only surpassed in France by Ernest Renan's (1823-92) Vie de Jésus (Life of Jesus, 1863) in the mid-nineteenth century. His paraphrase adopted the form of the burgeoning eighteenth-century French novel, and it displayed themes of sentimentality and the celebration, rather than denial, of human passions. Berruyer's text incorporated explanations from scientific fields such as botany, biology, and geography; it even reflected a propensity toward the promotion of an empirical epistemology and a belief that humans were fundamentally "good." In brief, Berruyer and the other "disciples" of Hardouin appropriated Hardouin's scholarship as a bridge into the intellectual world of the Catholic Enlightenment. ${ }^{69}$

\section{4}

Conclusion

At first glance, Jean Hardouin seems an unlikely figure to include in a discussion of the Enlightenment. Laughed at by the philosophes and abandoned by

66 Berruyer, Histoire du Peuple de Dieu, troisième partie.

67 Berruyer, Histoire du Peuple de Dieu, troisième partie, 1:xxviii.

68 The concept of the Enlightenment Bible is best articulated in Jonathan Sheehan, The Enlightenment Bible: Translation, Scholarship, Culture (Princeton, NJ: Princeton University Press, 2005). Although Sheehan does not mention Berruyer specifically—he focuses instead on bibles in England and Germany_I have argued elsewhere that Berruyer's paraphrase fits well within Sheehan's general schema. See Daniel J. Watkins, "An Enlightenment Bible in Catholic France: Isaac-Joseph Berruyer's Histoire du Peuple de Dieu (17281758)," in Vernacular Bibles and Religious Reform in the Middle Ages and Early Modern Era, ed. Wim François and August den Hollander (Leuven: Peeters, 2017), 273-96.

69 I have developed other connections between Berruyer's Histoire and many of the sensibilities of the Enlightenment in my doctoral dissertation: Watkins, "Enlightenment, Catholicism, Conservatism." For further explanation of some of the enlightened elements of the Histoire and Berruyer's connections with Hardouin, see also: Palmer, Catholics and Unbelievers, $68-76$. 
his own colleagues, he appears to be no one's intellectual predecessor. But he, like many others during the turn of the eighteenth century, dedicated much of his time and effort to solving one of the foremost intellectual questions of the day: how to arrive at a new kind of certainty. In an attempt to respond to skeptical arguments, however, Hardouin devised a critical system that was viewed as an unacceptable form of Pyrrhonism itself, and, in so doing, he pushed members of the French Society of Jesus to engage more actively in new philosophical arguments, new scholarly methods, and new forms of intellectual production. Although not the only spark for Jesuit engagement with enlightened epistemologies, Hardouin played an overlooked role in initiating it. His story suggests that internal pressures from radical members within the Society of Jesus itself drove other Jesuits to search for new intellectual tools for describing and defending the Catholic faith. When viewed in this way, Hardouin's career helps further explain French Jesuit involvement in the Catholic Enlightenment. Although Hardouin himself is difficult to place within Lehner's scheme, his colleagues who reacted against him and many of his "disciples" provide easier cases. Their engagement with new enlightened epistemologies, scientific methods and discoveries, and the "new language" of eighteenthcentury sentimental culture depict a French Society of Jesus that was seeking out novel ways to present Catholic theology and history. Indeed, some of the most active opponents of Hardouin, namely Tournemine and Buffier, became centerpieces of what Jeffrey D. Burson has described as the important Jesuit construction of a process of "Theological Enlightenment" in France. ${ }^{70}$ The case of Hardouin reveals that enlightened Catholicism - be it in the Jansenistinspired movement of "Reform Catholicism" or in the Jesuit variety described here-was not driven entirely by a reaction against the anticlerical authors of the "secular" Enlightenment; it was also driven by conflict within the Catholic Church and among Jesuits themselves. ${ }^{71}$

70 Jeffrey D. Burson, The Rise and Fall of Theological Enlightenment: Jean-Martin de Prades and Ideological Polarization in Eighteenth-Century France (Notre Dame, IN: University of Notre Dame Press, 2010), 41-54.

71 On Van Kley's concept of Reform Catholicism and how he feels it relates to Lehner's concept of the Catholic Enlightenment, see Dale K. Van Kley, Reform Catholicism and the International Suppression of the Jesuits in Enlightenment Europe, 1554-1791 (New Haven, CT: Yale University Press, 2018), introduction and ch. 1; Jeffrey D. Burson, The Culture of Enlightening: Abbé Claude Yvon and the Entangled Emergence of the Enlightenment (Notre Dame, IN: University of Notre Dame Press, 2019), introduction. This conclusion provides further weight, moreover, to Alan C. Kors's assessment of the importance of inter-Catholic philosophical conflicts in shaping much of eighteenth-century intellectual culture. See Alan C. Kors, Atheism in France, 1650-1729: The Orthodox Sources of Disbelief (Princeton, NJ: Princeton University Press, 1990); Naturalism and Unbelief in France, 1650-1729 (New 
Hardouin's story also sheds light on the importance of skepticism for initiating and perpetuating intellectual developments both in the late seventeenth century and beyond. Hardouin's preoccupations with historical truth and the challenges of Pyrrhonian skepticism illustrate how the "specter of skepticism," as Anton M. Matytsin has labeled it, lay in the background not just of philosophical but also of historical scholarship during the Enlightenment.72 Similarly, Hardouin's system and reactions to it exemplify how skepticism and anti-skepticism, while antithetical, could combine and overlap, leading intellectuals, in Matytin's words, into "accommodating and simultaneously mitigating the claims of Pyrrhonian skepticism."73 So too did Hardouin's legacy within the Society of Jesus, especially in the form of Hardouin's "disciples" who carried much of his system into the mid-eighteenth century, attest to the argument that Matytsin, Burson, and others are advancing that skepticism remained an important driving force for enlightened thought throughout the eighteenth century. ${ }^{74} \mathrm{~A}$ reassessment of the career of Hardouin, thus, reveals how the Catholic Enlightenment, or at least French Jesuit involvement in it, had indirect links to the crise pyrrhonienne.

\section{Acknowledgement}

I would like to thank Jeffrey D. Burson for the invitation to participate in this special issue and for his help in shaping my argument as well as Dale K. Van Kley, Matthew Goldish, Alice Conklin, Daniel Barish, and Joe Stubenrauch, all of whom contributed to this essay's development. I must also acknowledge the Moore Institute for the Humanities and Social Studies at the National University of Ireland Galway for its generous support in the form of a visiting research fellowship which allowed me time and resources to complete this article.

York: Cambridge University Press, 2016); Epicureans and Atheists, 1650-1729 (New York: Cambridge University Press, 2016).

72 Matytsin, Specter of Skepticism, 1 and 233-63.

73 Matytsin, Specter of Skepticism, 20.

74 See Jeffrey D. Burson and Anton M. Matytsin, ed., Skeptical Enlightenment:Doubt and Certainty in the Age of Reason, Oxford Studies on the Enlightenment (Liverpool: Liverpool University Press, 2019). 